\title{
AFBC Co-Firing of Coal and Hospital Waste
}

\author{
PECEIVED \\ JUI $1 / 19.97$ \\ Quarterly Report \\ November 1, 1996 - January 31, 1997
}

Work Performed Under Contract No.: DE-FC21-91MC27205

For

U.S. Department of Energy

Office of Fossil Energy

Federal Energy Technology Center

Morgantown Site

P.O. Box 880

Morgantown, West Virginia 26507-0880

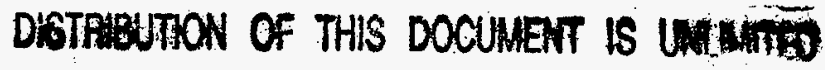<smiles>CC1=C(C)C2CCC1C2</smiles>

By

DONLEE Technologies, Inc.

693 North Hills Road

York, Pennsylvania 17402 


\section{Disclaimer}

This report was prepared as an account of work sponsored by an agency of the United States Government. Neither the United States Government nor any agency thereof, nor any of their employees, makes any warranty, express or implied, or assumes any legal liability or responsibility for the accuracy, completeness, or usefulness of any information, apparatus, product, or process disclosed, or represents that its use would not infringe privately owned rights. Reference herein to any specific commercial product, process, or service by trade name, trademark, manufacturer, or otherwise does not necessarily constitute or imply its endorsement, recommendation, or favoring by the United States Government or any agency thereof. The views and opinions of authors expressed herein do not necessarily state or reflect those of the United States Government or any agency thereof. 


\section{INTRODUCTION}

\section{Project Objective}

The project objective is to design, construct, install, provide operator training and start-up a circulating fluidized bed combustion system at the Lebanon Pennsylvania Veteran's Affairs Medical Center. This unit will co-fire coal and hospital waste providing lower cost steam for heating and possibly cooling (absorption chiller) and operation of a steam turbine-generator for limited power generation while providing efficient destruction of both general and infectious hospital waste. The steam generated is as follows:

- Steam $=20,000 \mathrm{lb} / \mathrm{hr}$

- Temperature $=353 \mathrm{~F}$ (saturated)

- Pressure $=125$ psig

- Steam quality $=\sim 98.5 \%$

\section{Reporting Period}

The reporting period covers activities from November 1, 1996 to January 31, 1997.

\section{Reporting Layout}

The Progress Reports will show progress and direction for each task and subtask. The Final Technical Report will also provide a coherent chronology of tasks and subtasks throughout the project. Weekly status meetings were held. In part, this report summarizes the primary issues discussed in those meetings relating to the completion of this project.

\section{TASK ONE - DESIGN, SPECIFY, PROCURE, INSTALL AND START-UP FACILITY}

\section{SUBTASK $1 A$ - Design}

Work on the Operation and Maintenance Manual continues. A pictorial account of the installation phase was prepared. As built drawings were released to LVA as part of their permit application package.

\section{SUBTASK 1-B - Equipment Purchase \& Fabrication}

The major pieces of equipment for this project have been procured and are in-place.

\section{SUBTASK 1-C - Installation}

The construction work was broken into smaller contracts allowing smaller constructors who specialize in specific portions of the construction package to install the equipment. The various subsystems (boiler, compressed air, service water, gas lines and startup bumer, ash reinjection and conditioning, limestone, baghouse, stack, coal handling, , combustor and hot cyclone, hospital waste and sterilization, boiler, analyzer and sample lines and main control system are in-place.

The painting of the structure and equipment is in the scope of the Lebanon VA Medical Center.

\section{SUBTASK 1-D - Shredder System Verification \& Testing}

Part of the Phase I Contract testing was completed at DONLEE's Pilot facility in June 1992. 


\section{SUBTASK 1-E - Startup}

Shakedown, startup and operation began after the completion of the equipment and instrument installation. Operator training sessions were held during this quarter to meet PA DER requirements, in addition to hands-on training of the operators during round-the-clock operation.

The Lebanon VA hired a person to be responsible for the repair, replace and maintenance of the Honeywell control system of the CFB facility.

\section{TASK TWO - OBTAIN PERMITS}

Due to the exhaustion of project funding, the LVA is responsible for obtaining the required for the Air Quality and Solid Waste permits from PA DEP.

\section{TASK THREE - PROCURE COAL, LIMESTONE AND ASH DISPOSAL CONTRACTS}

Early in the project the coal, limestone and ash disposal contracts could not be finalized because the initial supply date was in question due to NEPA approval related delays. Lebanon VA had received a supply proposal from Naughton Energy for coal, limestone and for ash disposal. During May 1994 the Lebanon VA set up a contract for procuring coal and limestone and for disposing of the generated ash when the facility is operational. Direnzo Coal Company is the ultimate supplier (subcontractor) of the coal and limestone. Coal shipments were received at the site on April 29, 1996, in mid-June, and during September and October 1996.

Naughton has a three-year contract (through September 1997) to supply the coal and limestone, and to dispose of the ash generated. The contract started in October 1994. From then until the time that the facility is operational, the right to purchase the coal and limestone and to dispose of ash is lost, or underutilized. Limestone and coal shipments have been obtained to do check outs and operaticn of the coal and limestone systems.

\section{TASK FOUR - CONDUCT ONE YEAR TEST PROGRAM}

This task was planned after the installation, pre-startup check outs and startup/shakedown of the facility have been completed. Stack testing and biospore testing are required by the Pennsylvania Department of Environmental Protection to demonstrate performance and for the proof of DRE (destruction removal efficiency), respectively. At least one test of each type is required by PA DEP, however, more tests can be required. Due to funding limitations, only about one each of the stack tests or biospore tests can be performed. A test matrix will also be performed to demonstrate the performance and operation limitations of the CFB facility and its emission levels, if possible.

Due to project funding limitations, testing has not been scheduled for this project. 


\section{TASK FIVE - PREPARE FINAL REPORT}

The report is due 3 months after the test program is completed. Information has been gathered concerning the equipment and facility. A matrix of tests that will demonstrate the performance and operation limits of the CFB system, quantify emission levels, identify problem areas and aid in performing scale-up analyses for future commercial designs was prepared.

\section{PROJECT COSTS}

The Lebanon VA Project Costs-to-Date are shown below

Lebanon VA Project Costs-to-Date Reported by Task

\begin{tabular}{|c|c|c|c|c|c|c|c|c|c|}
\hline TASK & Aug-96 & Sep-96 & Oct-96 & $\begin{array}{c}\text { Quarterly } \\
\text { Tolal } \\
8 / 1 / 16- \\
10 / 31 / 96\end{array}$ & Nov-96 & Dec-96 & Jan-97 & $\begin{array}{c}\text { Quarterly } \\
\text { Total } \\
11 / 1 / 97- \\
1 / 31 / 97\end{array}$ & $\begin{array}{c}\text { Contract } \\
\text { Costs } \\
\text { To-Date }\end{array}$ \\
\hline $\begin{array}{l}\text { TASK I- } \\
\text { Design/Build/nstall }\end{array}$ & $114,674.45$ & $124,008.45$ & $105,825.93$ & $344,508.83$ & $42,526.60$ & $30,252.31$ & $12,477.31$ & $85,256.22$ & $6,281,330.12$ \\
\hline TASK II - Permitting & & & & & & & & & $38,030.59$ \\
\hline $\begin{array}{l}\text { TASK III - Obtain } \\
\text { Coal, Limestane \& } \\
\text { Ash Contracts }\end{array}$ & & & & & & & & & $44,098.29$ \\
\hline TASK IV - Testing & & & & & & & & & \\
\hline $\begin{array}{l}\text { TASK V- } \\
\text { Final Report }\end{array}$ & & & & & & & & & \\
\hline PROJECT TOTAL & $114,674.45$ & $124,008.45$ & $105,825.93$ & $344,508.83$ & $42,526.60$ & $30,252.31$ & $12,477.31$ & $85,256.22$ & $6,684,816.17$ \\
\hline COST SHARE & $5,783.68$ & $7,273.73$ & $6,044.61$ & $19,101.92$ & $2,976.93$ & $2,325.85$ & 709.90 & $6,012.68$ & $418,386.07$ \\
\hline DOE BLLLING & 108.890 .78 & $116,734.73$ & $49,781.42$ & $325,406.91$ & $39,549.67$ & $27,926.46$ & $11,767.41$ & $79,243.54$ & $6,266,429.60$ \\
\hline
\end{tabular}

\section{SUMMARY}

Operating permits will be obtained after construction has been completed. Structural corrections have been made to make the facility meet the required building codes. Budget problems continued to occur through this reporting period. The unit was be turned over to the Veterans Administration due to the exhaustion of the project funding. 
M97053688

-

Report Number (14)DOE/MC/27205 = 5736

subl. Date (11) 199707

sponsor code (18) DOE/FE, XF

sc Category (19) $4 C-101, D O E / E R$

DOE 